\title{
Minimally invasive cardiac surgery - A single centre experience
}

\author{
Swapnil Deshpande*, Purushottam Deshpande, Shrikrishna Deshpande, Mukund Deshpande, Irshad Ahmed, \\ Jyoti Panhekar \\ From World Society of Cardiothoracic Surgeons 25th Anniversary Congress, Edinburgh \\ Edinburgh, UK. 19-22 September 2015
}

\section{Background/Introduction}

Minimally Invasive Cardiac Surgery is the Future of Cardiac Surgery. The patients who undergo these surgeries have better post-operative recovery, better cosmesis and faster recovery times.

\section{Aims/Objectives}

We present our data of 58 cases performed at our center in last 4 years.

\section{Method}

18 mitral valve replacements, 20 ASD closures, 14, Off pump CABGs, 6 Aortic Valve Replacements.

Off the 14 CABGs, 3 were Hybrid Procedures.

\section{Results}

Only one conversion to Median Sternotomy was necessary of the 58 cases which were operated. The operative time was definitely longer compared to the standard procedures but postoperative bleeding, ICU stay and Postoperative pain and ambulation were significantly smaller than standard surgeries. The patients have significantly reduced times to get back to complete work so the surgery also reduces the economic burden of the patients.

\section{Discussion/Conclusion}

Minimally invasive cardiac surgery is here to stay in cardiac surgery practice. Proper patient selection is necessary at least in the initial stages to avoid surgical misadventures. The availability of HYBRID Cardiac surgery suites definitely reduces the peripheral vascular complications. With proper training and availability of resources minimally invasive cardiac surgery can be performed at most centres with acceptable results.

Dr. KG Deshpande Memorial Centre, Nagpur, Maharashtra, 440010, India
Published: 16 December 2015

doi:10.1186/1749-8090-10-S1-A210

Cite this article as: Deshpande et al:: Minimally invasive cardiac surgery - A single centre experience. Journal of Cardiothoracic Surgery 2015 10(Suppl 1):A210.
Submit your next manuscript to BioMed Central and take full advantage of:

- Convenient online submission

- Thorough peer review

- No space constraints or color figure charges

- Immediate publication on acceptance

- Inclusion in PubMed, CAS, Scopus and Google Scholar

- Research which is freely available for redistribution 